\title{
Correction to: Triamcinolone Acetonide Extended-Release: A Review in Osteoarthritis Pain of the Knee
}

\author{
Julia Paik $^{1}$ - Sean T. Duggan ${ }^{1}$. Susan J. Keam ${ }^{1}$
}

Published online: 21 March 2019

(c) Springer Nature 2019

\section{Correction to: Drugs (2019) 79:455-462 https://doi.org/10.1007/s40265-019-01083-3}

The article Triamcinolone Acetonide Extended-Release: A Review in Osteoarthritis Pain of the Knee, written by Julia Paik, Sean T. Duggan, Susan J. Keam, was originally published Online First without open access. After publication in volume 79, issue 4, pages 455-462 Flexion Therapeutics, Inc., requested that the article be Open Choice to make the article an open access publication. Post-publication open access was funded by Flexion Therapeutics, Inc. The article is forthwith distributed under the terms of the Creative Commons Attribution-NonCommercial 4.0 International License (http://creativecommons.org/licenses/by-nc/4.0/), which permits any noncommercial use, duplication, adaptation, distribution and reproduction in any medium or format, as long as you give appropriate credit to the original author(s) and the source, provide a link to the Creative Commons license and indicate if changes were made.

The original article has been corrected.

Open Access This article is distributed under the terms of the Creative Commons Attribution-NonCommercial 4.0 International License (http://creativecommons.org/licenses/by-nc/4.0/), which permits any noncommercial use, distribution, and reproduction in any medium, provided you give appropriate credit to the original author(s) and the source, provide a link to the Creative Commons license, and indicate if changes were made.
The original article can be found online at https://doi.org/10.1007/ s40265-019-01083-3.

Julia Paik

demail@springer.com

1 Springer, Private Bag 65901, Mairangi Bay, Auckland 0754, New Zealand 